\title{
透過電子顕微鏡
}

\section{3. 電場・磁場可視化機能}

\section{進 藤 大 輔*}

\section{$3 \cdot 1$ は じめ に}

本入門講座の第 1 回と第 2 回では, それぞれ透過電子顕 微鏡の微細構造観察機能と組成・状態分析機能について概説 した. 最終回となる今回は, 透過電子顕微鏡の新しい機能と して注目を集めている電場と磁場の可視化機能について説明 する. 電場と磁場のナノスケールでの可視化機能は, 他の実 験手段では得難い機能であり, 特に先端材料の電気的・磁気 的特性を理解する上で極めて有用である. 電場・磁場を可視 化するには, 電子の波動性に着目し, その干渉効果を利用し た電子線ホログラフィーという実験技法を利用することにな る.

電子線ホログラフィーの実験技法は，1948年に D. Gabor (ガボール)によって提案された(1). もともとGabor が提案 したホログラフィーは, 電子顕微鏡の分解能の向上を目的と し，その対物レンズの収差を補正するためのものであった が, 当時干渉性の高い電子源がなかったため, この目的を達 成することはできなかった.この後, レーザーの出現によ

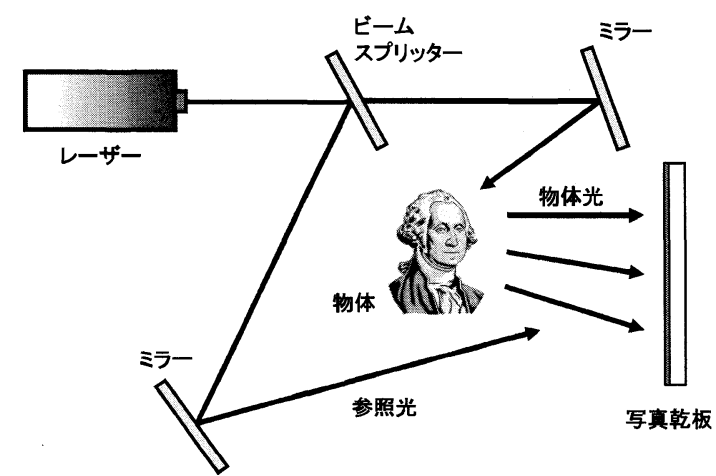

(a)
り, ホログラフィーの応用研究は光の分野で開花することと なった ${ }^{(2)}$. 近年, 電界放出型電子銃の開発により, 干渉性の 高い電子源が得られるようになり，電子顕微鏡の分野におい ても，このホログラフィーの実験が可能となっている.

ホログラフィー(holography) とは，注目する情報の“すべ て(ホロ：holo）”を“再現させる記録法 (グラフィー： graphy)”を意味している. レーザー光を用いたホログラフ ィーについて, 図 1 に基本原理が模式的に示してある. 通常 の写真撮影では, 二次元的な画像(強度分布)が得られるのみ であるが，図1(a)に示すように，ホログラフィーでは物体 光に参照光を重ね合わせ, 振幅に加え位相情報も写真乾板に 記録する．この写真乾板に再生光を照射させることにより， 図 1 (b)のように写真乾板から回折光を発生させる.ここ で, この回折光にはもともとの物体光の振幅と位相情報が含 まれているため, 図右より瞀き込久回折光を両眼で捉えれ ば，もともとの物体光と同様遠近感のある立体像(虚像)が観 察できることになる. 以下では, 電子線を用いたホログラフ ィーにおける位相再生プロセスについて数式を用いて概説す るが，そこでは試料を透過した電子の位相情報を再生させる

図 1 レーザー光を用いたホログラフィーの原理を示す模式図.

* 東北大学教授 ; 多元物質科学研究所 (干980-8577 仙台市青葉区片平2-1-1)

Transmission Electron Microscope 3. Function of Visualization of Electric and Magnetic Fields; Daisuke Shindo(Institute of Multidisciplinary for Advanced Materials, Tohoku University, Sendai)

Keywords: electron holography, biprism, electric field, magnetic field, electromagnetic force

2005年 9 月20日受理 
ことにより，試料の厚さ情報は勿論のこと，電子の位相に影 響を及ぼす電場や磁場の情報が記録され，顕微鏡外でそれら を定量的に再生できることがわかる。

\section{$3 \cdot 2$ 電子線ホログラフィーの原理}

電子線ホログラフィーは，「電子顕微鏡内での電子波の位 相情報の記録」と，「光学再生システムあるいはコンピュー タを用いた位相再生」の二段階からなる．位相情報を記録す るための電子波の干渉法には種々の様式があるが，本稿で は，最近最も多く用いられてきているバイプリズムけを用い た電子波干渉法の原理について述べる。 また，位相再生につ いては，最近多用されているコンピュータを用いたディジタ ル画像データ処理法に基づいて説明する. 図 2 に, 電子線ホ ログラフィーの原理を模式的に示す. 物体内外の電場や磁場 による入射電子の振幅と位相の变化を示す波動関数は，一般 的に

$$
q(r)=A(r) \exp (i \phi(r))
$$

と記述することができる．ここで，汎用の電子顕微鏡法によ る観察を考えると，分解能や像の拡大率を無視すると得られ る電子顕微鏡像の強度は式 (1)より,

$$
I(r)=|q(r)|^{2}=A^{2}(r)
$$

となる.式 (2)より, 汎用の電子顕微鏡法では, 入射電子 の試料内での吸収や回折による振幅の減衰 $(A(r))$ は評価で きるが，電場や磁場の影響を示す位相情報 $(\exp (i \phi(x, y))$ は 得られないことがわかる．電子線ホログラフィーでは，電 場・磁場の影響を受けた電子波(物体波) と真空中を伝播した 電子波(参照波)をバイプリズムによって偏向させそれぞれ $-\alpha_{\mathrm{h}} / 2$ と $\alpha_{\mathrm{h}} / 2$ の角度で干渉させ，位相情報をこの干渉縞 (ホログラム)に記録する (図 2)．このホログラムの強度分布 I は，

$$
\begin{aligned}
I_{\mathrm{h}}(r) & =\left|A(r) \exp \left(-\pi_{\mathrm{i}} \frac{\alpha_{\mathrm{h}}}{\lambda} x+i \phi(r)\right)+\exp \left(\pi_{\mathrm{i}} \frac{\alpha_{\mathrm{h}}}{\lambda} x\right)\right|^{2} \\
& =1+A^{2}(r)+2 A(r) \cos \left(2 \pi \frac{\alpha_{\mathrm{h}}}{\lambda} x-\phi(r)\right)
\end{aligned}
$$

と与えられる. 右辺下段の第 3 項に位相変化 $\phi(r)$ が含まれ ており，このホログラムにフーリエ変換演算を施すことによ り，電場や磁場による入射電子の位相抢よび振幅の変化が数 值データとして再生できることになる(3)，通常，再生された 位相変化 $(\phi)$ を $\cos \phi$ として記述し, 電場や磁場の分布を位 相再生像として 2 次元画像として表示する.

ここで, 図 2 右上の試料断面に扔いて, 試料通過後のC 点と D 点間で生じる位相差は電位 $\varphi(r)$ を用いて

$$
\phi\left(r_{\mathrm{C}}\right)-\phi\left(r_{\mathrm{D}}\right)=\sigma\left[\int_{\mathrm{A}}^{\mathrm{C}} \varphi(r) d z-\int_{\mathrm{B}}^{\mathrm{D}} \varphi(r) d z\right]
$$

と記述できる. 式 (4)の $\sigma$ は相互作用定数と呼ばれ, 加速 電圧 $V$ ，電子の波長 $\lambda$ で与えられる。，一方，磁場による位 相变化は磁束密度 $\boldsymbol{B}$ を用いて,

†電子線用のバィプリズムは, 径が $1 \mu \mathrm{m}$ 以下の 1 本のフィラメ ントと一対のアースからなり, 電圧を印加することにより電子 波を偏向させる.

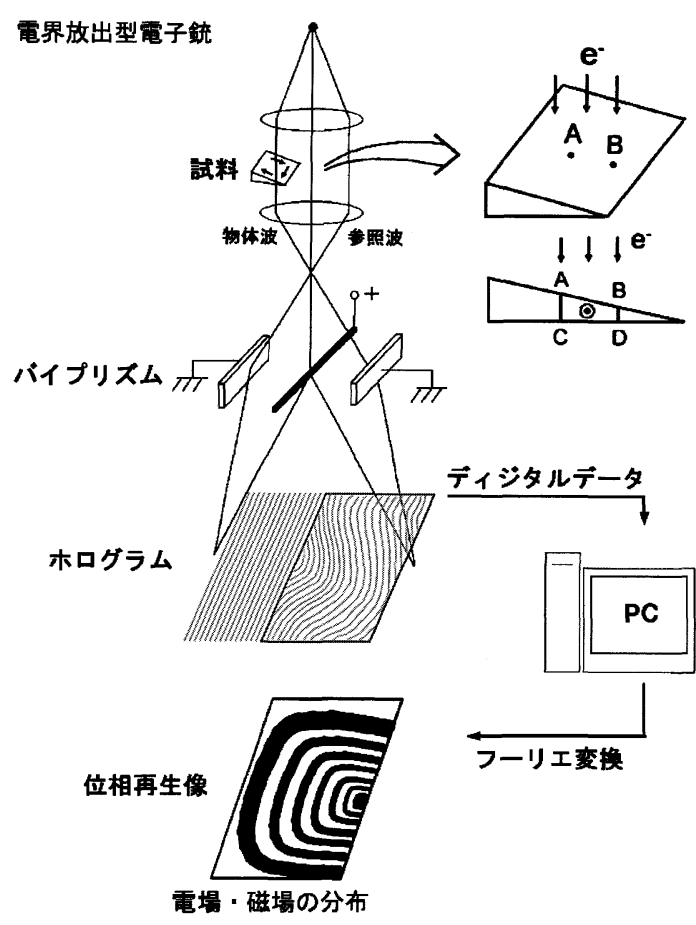

図 2 電子線ホログラフィーの原理を示す模式図.

$$
\begin{gathered}
\phi\left(r_{\mathrm{C}}\right)-\phi\left(r_{\mathrm{D}}\right)=\frac{\mathrm{e}}{\hbar} \iint \boldsymbol{n} \cdot \boldsymbol{B}(r) d S \\
\left(\hbar=\frac{\mathrm{h}}{2 \pi}, h: \text { プランク定数 }\right)
\end{gathered}
$$

と記述できる ${ }^{(3)}$. $\boldsymbol{n}$ は, 電子線に平行な面 $\mathrm{S}$ (図 2 右上の領 域 $\mathrm{ABDC}$ )の法線単位ベクトルに対応する.ここで, もし試 料の厚みが一定であれば，電位のみが存在する場合には，式 (4)より C 点と D 点での電子の位相は同一となり, 位相変 化は生じない。また，式 (4)の電位がスカラー量であるの に対し, 式 (5)の磁束の方はベクトル量であることに注意 したい，つまり，電子が試料を通過する際，電位による位相 変化は単調増大となるのに対し, 磁束の場合にはその位相変 化が磁束の方向に依存し増減することになる.

図 3 は, 対物レンズの磁場を低く抑えて撮影した非晶質磁 性体 $\mathrm{Fe}_{73.5} \mathrm{Cu}_{1} \mathrm{Nb}_{3} \mathrm{Si}_{13.5} \mathrm{~B}_{9}$ のホログラム (a) と位相再生像 (b) の例である ${ }^{(4)}$ 。図 3(a)のホログラムの干渉縞は，真空中で は直線であるが試料内では磁場と電場の影響を受け曲線を描 いている，特に，図中の $\mathrm{P}, \mathrm{R}$ の付近では，干渉縞が試料内 部に向けて大きく偏向しているのに対し，Qでは逆に試料端 側に縞が変位しており，これらの場所で位相変化 $(\phi)$ の符号 に違いが生じていることがわかる。このことは，図 3(b)の 位相再生像の $\mathrm{P}, \mathrm{R}$ と $\mathrm{Q}$ 領域で，矢印で示す磁束線の方向が 反対であることと対応している．この試料の形状がくさび型 であることを考慮し，その平均内部電位 ${ }^{\dagger \dagger}$ と磁束の位相再生

†帯電していない試料外では，原子を構成する陽子と電子の 正・負の電荷が相殺し電位はゼロとなるが，試料内の特に原 子核の近くでは陽子の正電荷の影響で電位は高くなる．試料 内での平均の電位は平均内部電位と呼ばれ, 通常物質により 異なるが数ボルトから 20 ボルト程度の值をとり，一般に物質 を構成する元素の原子番号や密度の増大とともに大きくなる。 

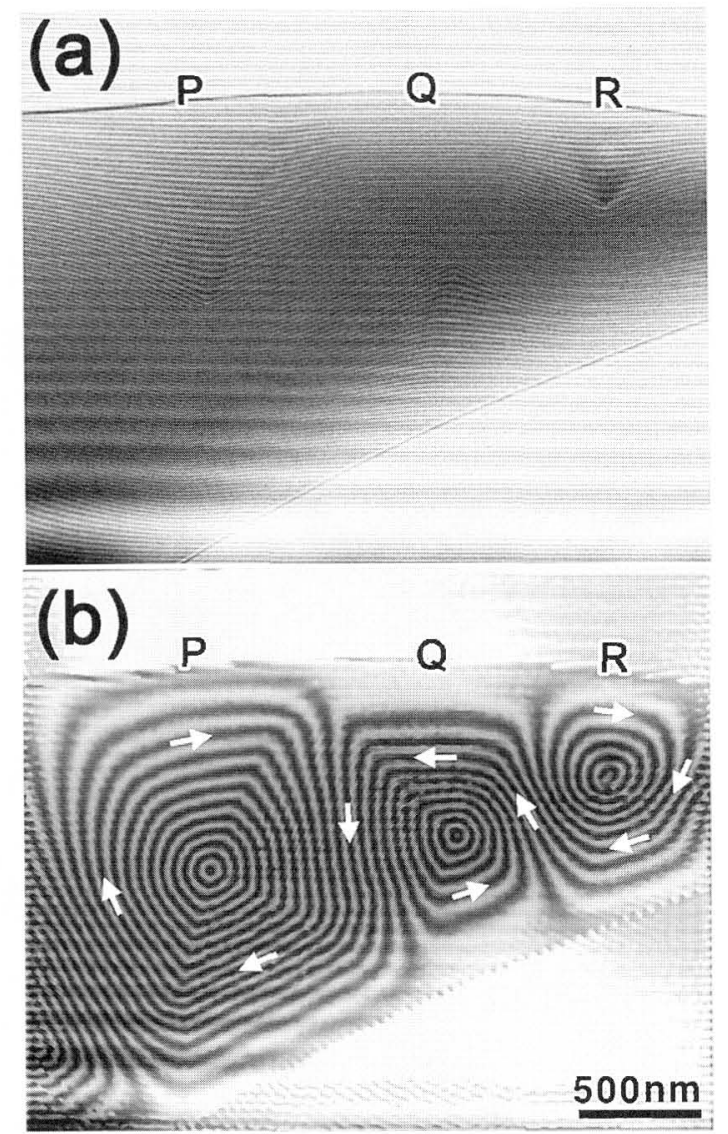

図 3 急冷した $\mathrm{Fe}_{73.5} \mathrm{Cu}_{1} \mathrm{Nb}_{3} \mathrm{Si}_{13.5} \mathrm{~B}_{9}$ のホログラム (a) と 位相再生像 (b).（b)の白矢印は, 磁束線の方向 を示す。

像に及ぼす影響を示したのが図 4 のシミュレーションであ る. (b) の平均内部電位の久が存在する場合には, 試料の端 から厚い領域にかけてゆっくりと位相が変化するのに対し， (c)の磁場の反が存在する場合には，厚くなるに次第に等高 線の密度が増大している. 内部電位と磁場の両方の存在する 場合には, これらが重畳されるが, 磁場の方向により特に試 料端で位相変化に違いが生じることがわかる((d), (e)). 図 3(b)のP, Rの状況は, 図 4 (d) に対応し, 図 3(b)のQ Q は図 4 (e) に対応していると理解できる。したがって，試料厚み が一定の場合や, 厚久の変化が緩やかで比較的厚い試料で は, 近似的に位相再生像には磁束線の情報の及が反映される と解釈できる。しかし, 磁性微粒子や磁化が著しく小さい磁 性体では, 磁場よりも内部電位が電子の位相により大きな変 化をもたらすことになる。

\section{$3 \cdot 3$ 電位分布の評価}

図 5 は, 電界電子放出機能を有する物質として注目されて いる $\mathrm{WO}_{3}$ ナノワイヤーの電位分布を電子線ホログラフィー によって評価したものである(5)。(a) は通常の透過電子顕微 鏡像であり，ナノワイヤーの先端部の形態が観察されてい る. (b)は，電子線ホログラフィーによって得られた位相再 生像であり,ナノワイヤーの試料端近傍で試料厚久が急激に 増大するため, 内部電位による電子の位相変化に伴う等高線 (a)
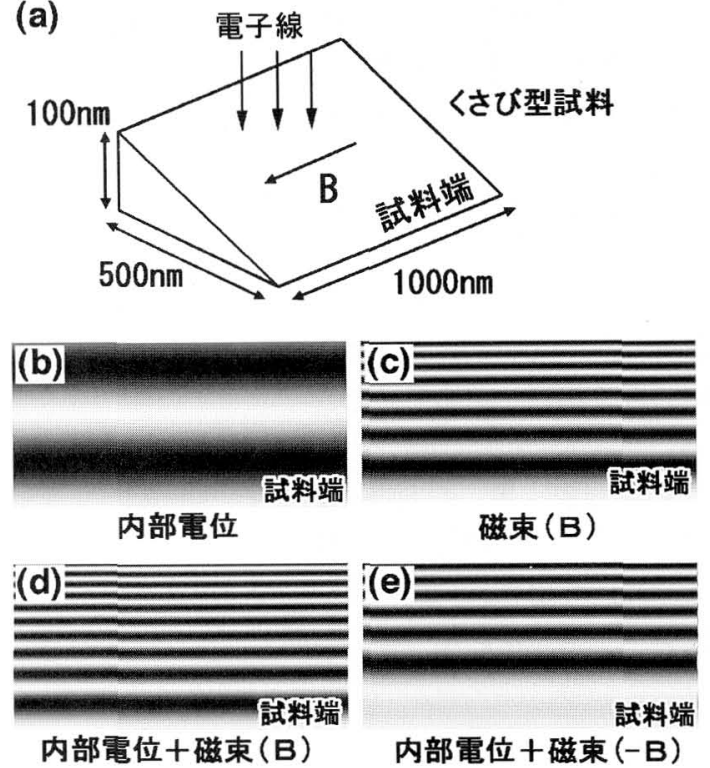

図4 位相再生像のコンピュータシミュレーション. (a)シミュレーションに用いた試料の形状. (b) 電場 (内部電位 $17 \mathrm{~V}$ ) のみを考慮した場合。(c) 磁束 (1.2 T)の及を考虑した場合．（d）（a）に示す 磁束と内部電位を考慮した場合. (e)（a）と反対 向きの磁束と内部電位を考慮した場合.

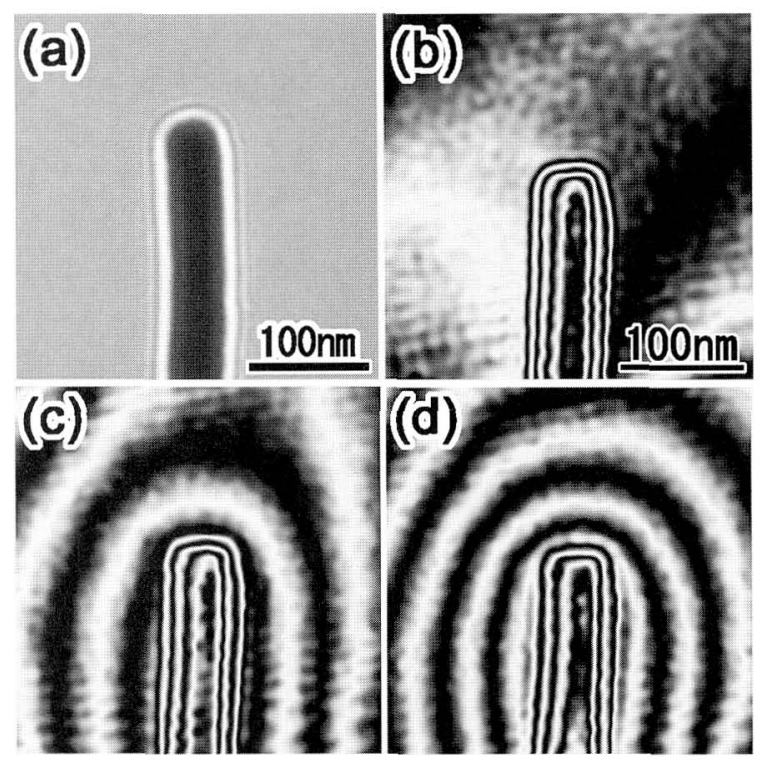

図 $5 \mathrm{WO}_{3}$ ナノワイヤーの透過電子顕微鏡像 (a) と電压 を印加した折の位相再生像 (b)-(d). (b) 0 V. (c) $60 \mathrm{~V}$. (d) $100 \mathrm{~V}$.

が認められる．これに対し，(c)と(d)はこのナノワイヤー に電圧をそれぞれ $60 \mathrm{~V}$ と $100 \mathrm{~V}$ 印加した際の位相再生像で あり,ナノワイヤーの周囲に電压印加に伴う電位分布が生 し，電压の增大とともに，等高線の数が増大する様子が捉え られている.なお，これらの電位分布は電子線方向へ投影し たものである．屯た，電場分布を求めるには電位を微分する 必要がある，極最近には，透過電子顕微鏡に導入されている 熱電界放出型電子銃に用いられている $\mathrm{W}-\mathrm{Zr}_{2} \mathrm{O}$ ティップの 電位分布も観察され，未使用と使用後のティップの形状変化 

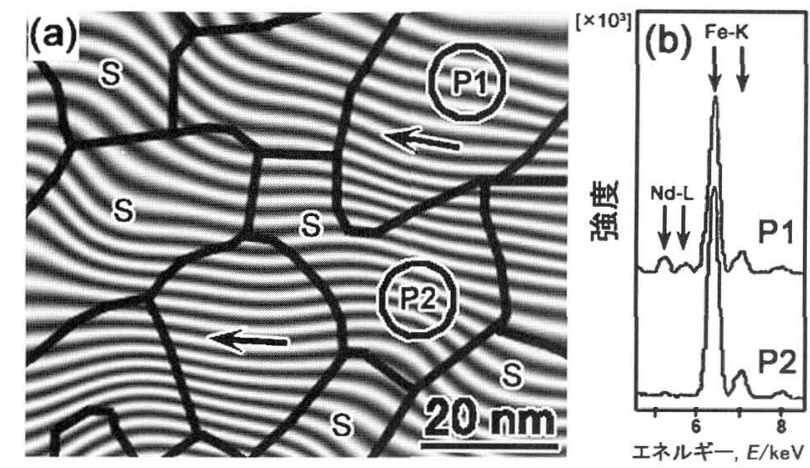

図 6 (a) 電子線ホログラフィーによって得られたナノ コンポシット磁石 $\mathrm{Nd}_{4.5} \mathrm{Fe}_{77} \mathrm{~B}_{18.5}$ の位相再生像. 黑の線は結晶粒界を示す。(b) (a)のP1 と P2 の 領域で得られた特性 X 線スペクトル. P2 は $\mathrm{Nd}$ を含まない軟磁性相 $\left(\mathrm{Fe}_{3} \mathrm{~B}\right)$ であることがわかる。

とともに，これによる電位分布の微細な変化も詳細に解析さ れている(6).

\section{$3 \cdot 4$ 磁束分布の評価}

最近，永久磁石としての磁気特性を向上させることを目的 に, 高い結晶磁気異方性を有する硬磁性相と高い飽和磁束密 度を有する軟磁性相をナノスケールで組み合わせたナノコン ポシッッ磁性体が精力的に開発されてきている.図 $6(\mathrm{a})$ は, ナノコンポショット磁性体 $\mathrm{Nd}_{4.5} \mathrm{Fe}_{74} \mathrm{~B}_{18.5} \mathrm{Cr}_{3}$ の位相再生像 の例である ${ }^{(7)}$. 先の講座で解説した透過電子顕微鏡の微細構 造観察機能と組成分析機能(図 6(b)) を用いることにより, 本試料が結晶粒 $10 \sim 30 \mathrm{~nm}$ の硬磁性相 $\mathrm{Nd}_{2} \mathrm{Fe}_{14} \mathrm{~B}$ と軟磁性 相 $\mathrm{Fe}_{3} \mathrm{~B}$ (図中 $\mathrm{S}$ で示す) から構成されているのがわかる。 ま た, 試料厚久が均一なため, 図 $6(\mathrm{a})$ の位相再生像は内部ポ テンシャルの影響を受けず磁束の情報のみを示している．矢 印方向に磁束線がほぼ平行に揃って硬磁性相と軟磁性相を貫 いているが，これは軟磁性相と硬磁性相間での交換相互作用 によって生じていることを示している，また，この均一で平 行な磁束線の分布は, 本試料の高い残留磁束密度 $(\mathrm{Br}=1.11$ T) とよく対応しているものと理解できる.このように, 電 子線ホログラフィーではナノスケールでの磁性体間に働く磁 気的相互作用を，その力の源である磁場を可視化することに より明らかにでき，その特性との対応が理解できることがわ かる。

\section{$3 \cdot 5$ お りり}

自然界には，相互作用を生み出す基本的な力として，重力 の他, 強い力と弱い力, そして電磁気力の 4 つが存在す る. 重力は, 天体の運動に及ぶ巨視的なスケールで重要な役 割を担い, 強い力と弱い力は主に原子殼内での相互作用に関 わるものであることを考慮すると，我々の身の回り(身体内 の営み・機能も含め), 特にミクロな世界の相互作用を生み 出久だす基本となる力の殆どが電磁気力であると理解でき
る. 電磁気力の源は電場と磁場であり, 電子線ホログラフィ 一によってこれらの場を定量的に可視化できることの意義は 極めて大きいと言える.

近年の透過電子顕微鏡への電界放出型電子銃とバイプリズ ムの導入を踏末え, 電子線ホログラフィーによる電場と磁場 の可視化により物質の内部ポテンシャルの測定や磁束分布の 解析が実施されてきたとは言え, その応用範囲はまだまだ限 られたものとなっているのも事実である. しかし, 本講座で 紹介した電圧印加, また強い磁場の印加 ${ }^{(8)}$ も顕微鏡内で実施 することが最近可能となっており, その場実験による先端材 料内外の電位分布や磁束の変化の定量的な解析も実現してい る. 今後, 電子線ホログラフィ一技術に関わるハード・ソフ 卜両面での一層の発展により, 極微弱な電場と磁場の検出が 可能となり，ナノテクノロジーを支えるナノマテリアルをは じめ広範な物質へ本技法が適用され，これら物質の機能発現 機構の解明が飛躍的に進展することを期待したい。

\section{文献}

(1) D. Gabor: Nature, 161 (1948), 777-778.

(2) E. N. Leith and J. Upatnieks: J. Opt. Soc. Am., 53(1963), 1377-1381.

（3）進藤大輔：日本応用磁気学会誌，27(2003), 1000-1006.

(4) D. Shindo, Y.-G. Park and Y. Yoshizawa: J. Magn. Magn. Mater., 238(2002), 101-108.

(5) D. Shindo, H. S. Park, Y. Murakami, Y.-L. Chueh, M.-T. Chang and L. J. Chou: Proceedings of IUMRS-ICA 2004 International Conference in Asia, Taiwan, Hsinchu, 08: 1-12.

(6) T. Oikawa, T. Tomita, H. S. Park and D. Shindo: Microsc. Microanal, 11 (Suppl. 2), (2005), 568-569.

( 7 ) D. Shindo, Y.-G. Park, Y. Murakami, Y. Gao, H. Kanekiyo and S. Hirosawa: Scripta Mater., 48(2003), 851-856.

(8) D. Shindo, Y.-G. Park, Y. Gao and H. S. Park: J. Appl. Phys., 95 (2004), 6521-6526.

電子線ホログラフィーに関する書籍

(1) A. Tonomura: Electron Hologarphy, $2^{\text {nd }}$ Edition, Springer-Verlag, (1999).

〜ホログラフィーの基本原理と各種材料の解析例が系統的に 説明されている．ローレンツ顕微鏡法を用いた超伝導体中の 磁束量子の観察についても記されている.

(2) E. Völkl, L. F. Allard and D. C. Joy: Introduction to Electron Holography, Kluwer Academic/Plenum Publishers (1999).

〜電子線用バイプリズムを考案した Möllenstedt(メーレンシ ュッテット)自身による, 電子線ホログラフィー草創期の叙述 をはじめ, 数多くの研究者による電子線ホログラフィーの解 析技術，応用例に関する解説記事が編集されている.

( 3 ) D. Shindo and T. Oikawa: Analytical Electron Microscopy for Materials Science, Springer-Verlag, (2002), pp. 116-125. 〜各種分析法とともに, ローレンツ顕微鏡法そして電子線ホ ログラフィーの原理と応用例が詳述されている.
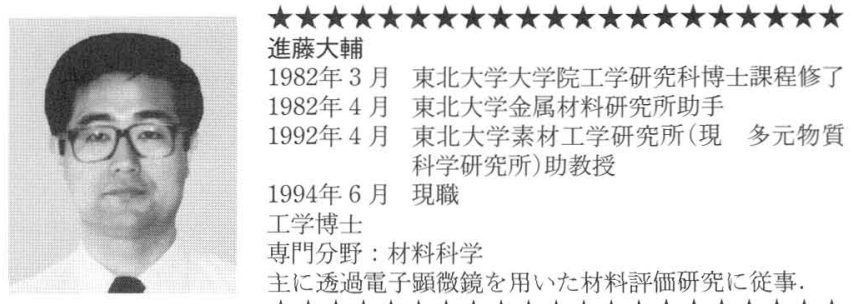

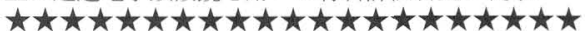

